\title{
Indicator studies: a critical review and a new data- presentation method
}

\author{
PER SMED
}

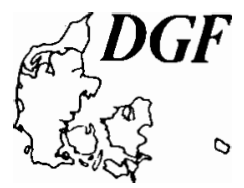

Smed, P.: Indicator studies: a critical review and a new data-presentation method. Bulletin of the Geological Society of Denmark, Vol. 40, pp. 332-340. Copenhagen, 1993-12-30. https://doi.org/10.37570/bgsd-1993-40-16

This paper deals with general problems of indicator collection and introduces a new datapresentation method, named the circle-map method. The advantages of this method is demonstrated by collecting a wide spectrum of Scandinavian and Baltic rock types in two Danish localities. It is concluded that an indicator count should be made in situ and comprise at least 50 stones, and that the rock types used should represent parent areas as evenly distributed as possible throughout the Scandinavian and Baltic regions. The circle maps indicate the routeway of ice flow from the Scandinavian mountains to the locality dealt with. It emphasizes variations in indicator content and may, therefore, show the lateral displacement of ice-flow routes which should be expected from a glaciological point of view. In addition, the method makes it possible to distinguish between directly brought stones and contaminating stones.

Per Smed, Stiholmsvej 1, DK-3460 Birkerød, Denmark. 29th February 1992.

\section{Introduction}

V. Milthers (1909) introduced an indicator-count method using about 15 rock types, or - in a narrow version - only 6 types. This method was widely used by V. Milthers (1934), K. Milthers (1941, 1942), and Wennberg (1949). Hesemann (1935) and Andersen (1945) discussed critically the method of Milthers and found it defective. Gry (1974) and Krüger (1974) demonstrated that the various indicator types used by Milthers differ in average particle size. With reference to the indicator-count methods of Hesemann $(1931,1936)$ and Lüttig (1956), Krüger (1974) proposed that an extension of the number of rock types used could improve the method. From bedrock localities in Sweden he collected a large number of rock types - mainly porphyries and granites - which were later recognized in Denmark. Following Krüger's proposal, the present author intended to examine the usability as indicators of a wide spectrum of rock types. On the basis of Kriuger's collection and the indicator handbook by Hesemann (1975) and of geological literature as well the author has been able to identify about 100 rock types from the Scandinavian and Baltic regions (Smed 1989).

The aim of this paper is threefold. First, it reviews the general problems of indicator collection. Secondly, it

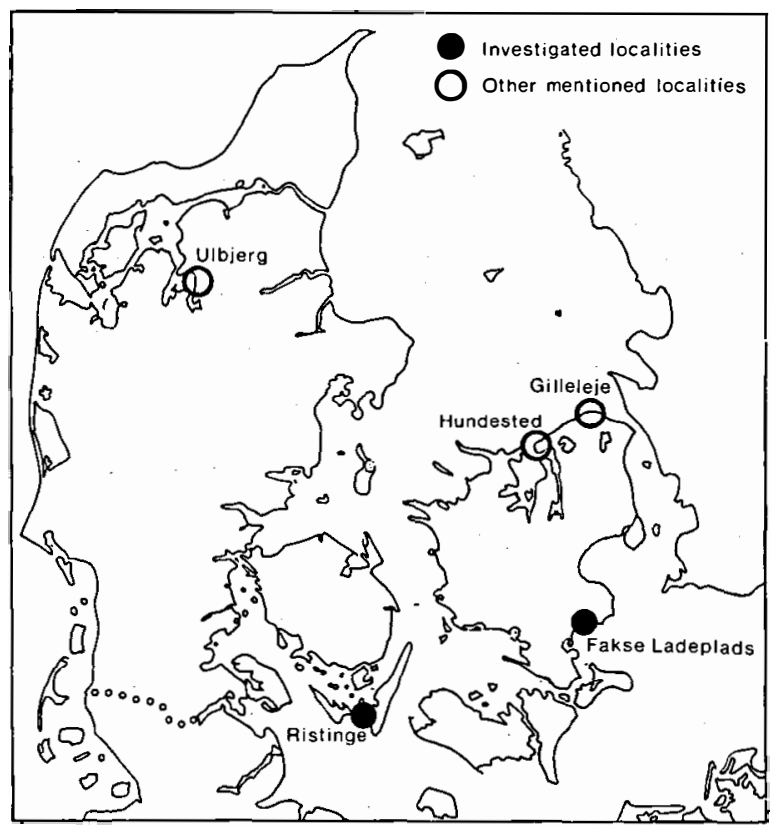

Fig. 1. Locality map. 
introduces a new data-presentation method the applicability of which is demonstrated by collecting a wide range of indicator types in two Danish localities (fig. 1): Ristinge cliff, Langeland, and the cliffs southwest and northeast of Fakse Ladeplads, Sjælland. Finally, it compares the new method with classical presentation methods.

\section{Problems of indicator collection}

The size problem. It is well-known that plutonites display larger average particle sizes than volcanics. This was demonstrated by this author by carrying out two counts of larvikites and rhomb porphyries (similar in chemical composition) at Ulbjerg beach, Jylland (fig. 1). Within $400 \mathrm{~m}$ of the beach 52 larvikites and 25 rhomb porphyries with a diameter larger than $30 \mathrm{~cm}$ were obtained. Among stones smaller than $30 \mathrm{~cm}$ only 15 larvikites but 30 rhomb porphyries were registered within $4 \mathrm{~m}$ of the same beach. Both rock types originate from the Oslo field, but if they had originated from two different parts of Scandinavia, the two counts would most probably have led to two different conclusions regarding the provenience of the material. It must be concluded that it is advisable not to combine "small" indicator types (porphyries) from one region with "large" types (plutonites) from another region.

V. Milthers (1909) suggested that differences in mean size between volcanic and plutonic erratics result from differences in resistance to abrasion. In order to use rock types with equal properties only he recommended the exclusion of plutonites. Even so, in the less narrow elaboration of his method Milthers counted both "large" indicators from one district and "small" ones from another district, for example Åland granites and porphyry types from Dalarna. Krüger (1974) explained the difference in mean size between volcanic and plutonic erratics merely as an effect of differences in joint spacing on the parent localities: generally, volcanic rocks have tightly spaced joints, whereas granites display widely spaced joints.

To eliminate the size problem the present author has counted both "small" and "large" rock types from parent areas throughout Scandinavia, so that "blind" areas are avoided (fig. 2). By using this procedure, however, counts among large boulders and small stones, respectively, will not demonstrate a spectrum of identical rock types, but they will show the same pattern of parent regions in a general way.

Resistance of rock types. J.H. Barry (pers. comm., 1986) made an experiment in which porphyry and granite stones were tumbled constantly with a mixture of sand, small flint particles, and water in a tumble polisher for 58 days. The stones were weighed before and after tumbling. The porphyries lost totally $8.6 \%$ of their initial weight, whereas the granites lost as much as $16.4 \%$. The explana- tion could be that the uneven crystal sizes characterizing many granites make this rock type susceptible to weathering, because large crystals expand and shrink more than small ones. Contrary to this, the groundmass of porphyries is massive with few points of attack. Due to the large extension of granitic bedrock in Scandinavia, however, granite erratics are more abundant than volcanics in Danish tills.

During glacial erosion the bedrock is disintegrated along weakness planes (Boulton 1974, Sugden \& John 1976). Later, in transport, the stones become slightly rounded, but they diminish only slowly in size (Humlum 1985). The lithological composition of glacial deposits shows that glaciers can transport even soft rocks, such as limestones and shales, over long distances without pulverizing them. The numerous clasts of Palaeozoic limestones occurring in Danish tills were transported from the Baltic area by ice over distances of at least $200-300 \mathrm{~km}$. Milthers' (1909) statement about differences in resistance to glacier transport is therefore exaggerated.

Number of indicator types selected for use. In the narrow elaboration of his indicator method Milthers (1909) used only 6 porphyry types originating from three areas: (1) the Oslo field, (2) Dalarna, and (3) the bottom of the Baltic sea. According to Milthers (1909) indicators should be common, easily defined, and the parent rock had to be found in one area only. However, in spite of their occurrence both on the bottom of the Baltic sea and in several areas in central Sweden, Palaeozoic limestones are also useful as indicators. In this work such rock types are termed statistical indicators. In contrast to Milthers $(1909,1934)$, Hesemann $(1931,1936)$ counted a large

Table 1. Indicator count $A$ in the NE-ice till in Ristinge cliff, Langeland, Denmark. The index numbers refer to same numbers as shown in Fig. 5.

\begin{tabular}{lc}
\hline Index Indicator Type & $\begin{array}{c}\text { Number of } \\
\text { specimens }\end{array}$ \\
\hline
\end{tabular}

\begin{tabular}{lll}
\hline 12 & Filipstad granite, brown-violet var. & 4 \\
13 & Filipstad granite, southern var. & 1 \\
14 & Kinne "diabas" & 7 \\
16 & Granate amphibolite & 3 \\
18 & Scanian granulite & 6 \\
19 & Särna porphyry & 2 \\
20 & Dala sandstones & 9 \\
21 & Dala ignimbrite & 1 \\
21 & Bredvad porphyry & 1 \\
22 & Siljan granite & 2 \\
26 & Kinda granite (Östgöta granite) & 2 \\
27 & Red Småland granite & 3 \\
30 & Pink Växjö granite & 2 \\
33 & Scanian basalt & 8 \\
34 & White Scolithus sandstone & 2 \\
41 & Red sandstones (- No. 20) & 5 \\
43 & Palaeozoic limestones & 3 \\
46 & Åland rapakivi & 2 \\
46 & Åland quartz porphyry & 64 \\
\hline Total & & \\
\hline
\end{tabular}




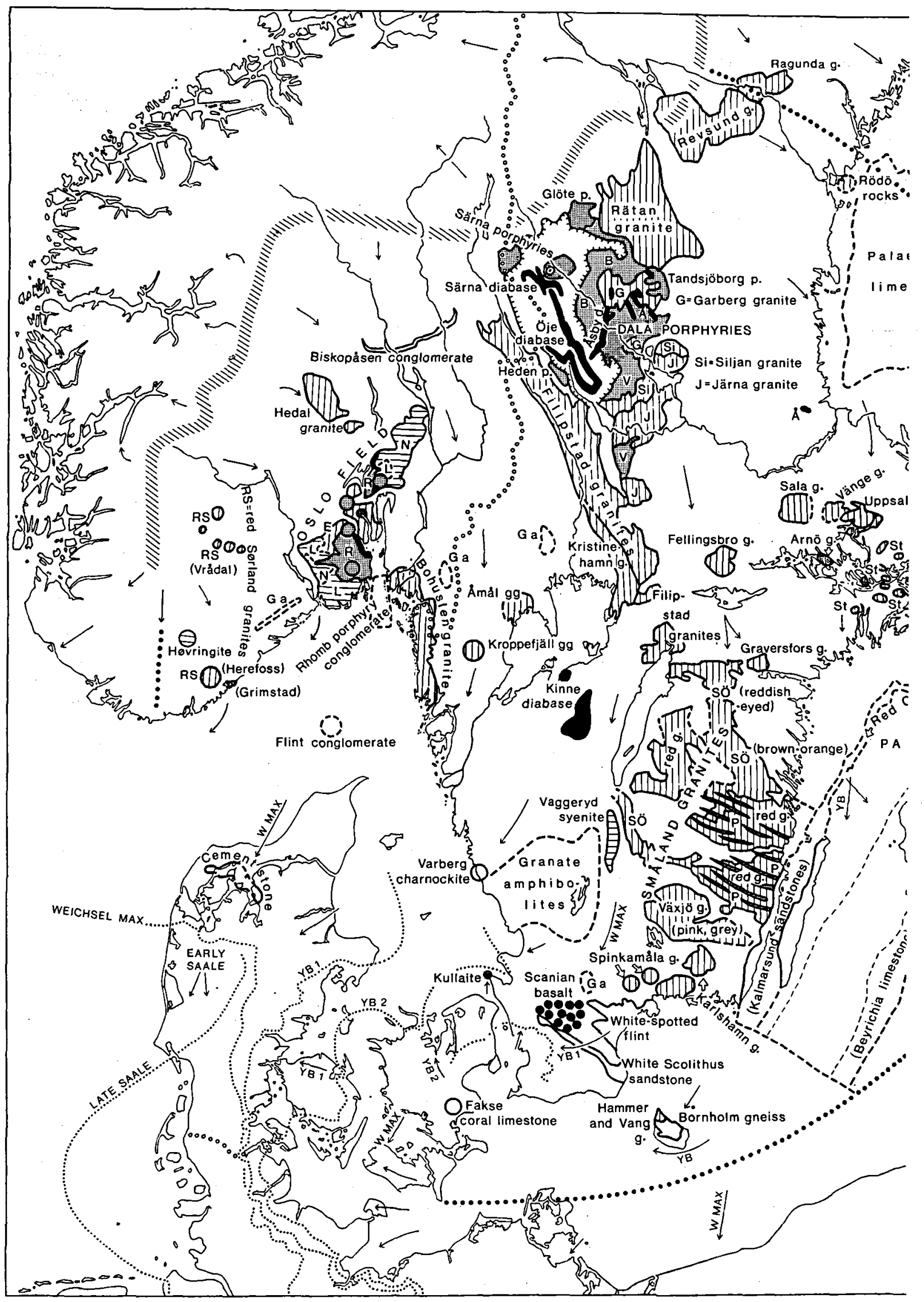




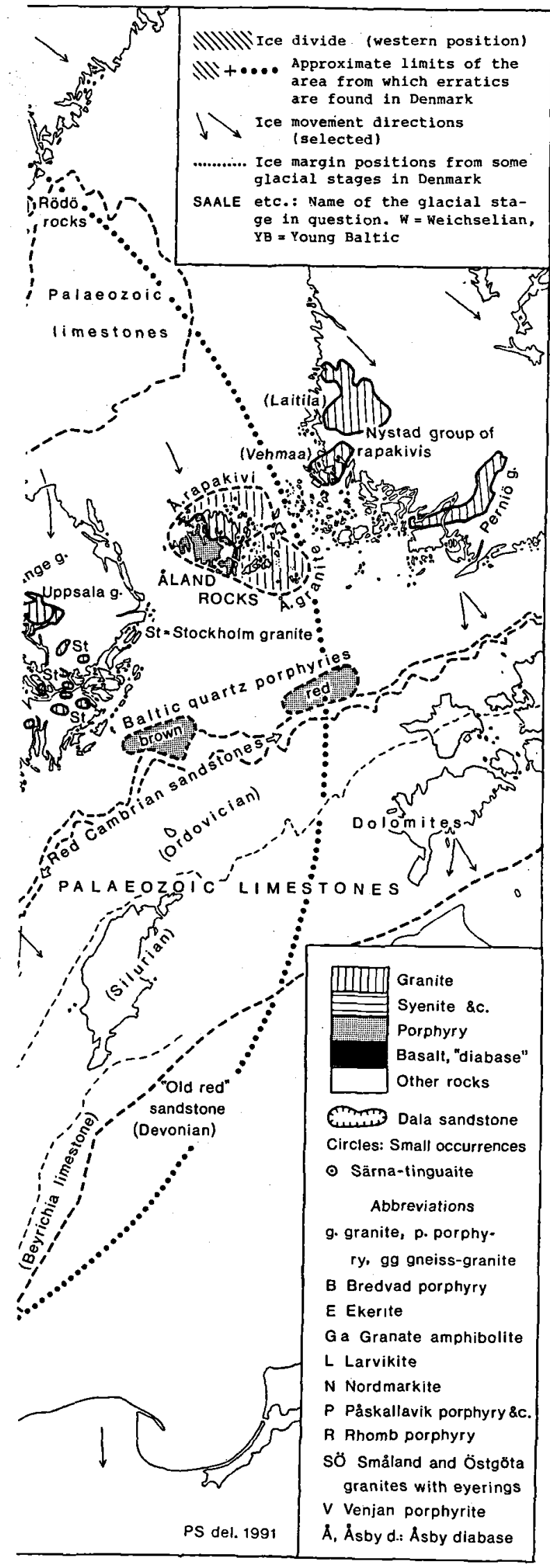

Fig. 2. Simplified map showing indicator parent areas. In the sea and in areas where the rock type boundaries have never been mapped with precision, they are shown by dotted-and-dashed lines. Scanian granulite has been omitted because of lack of space on the map (cf. fig. 5).

number of rock types. In the course of time he became able to identify more than 200 indicator types.

Comparing the two indicator methods of Milthers and Hesemann, the present author has found that the method of Milthers ignores possible information. Hesemann (1935) pointed out that "any detail can be the clue to one problem or another". Furthermore, it is the experience of the author from several beach stone counts in Denmark that counts including Hesemann's broad spectrum of rock types will reflect the geology of the nearby cliff rather precisely. For example, the bulk of the till exposed in the Hundested cliff, Sjælland, (fig. 1) has been deposited by an ice coming from east-northeast across Sweden; only minor parts of the cliff face consist of till deposited by ice coming from Norway (Sjørring 1974). Accordingly, a significant majority of Hesemann's indicators counted on the beach originated from Sweden (Kinne "diabases", Filipstad and Kristinehamn granites) and only few indicators represented the Oslo field. In beach stone counts made by Milthers (1942), however, the number of rhomb porphyries exceed the number of Dala porphyries, which were the only Swedish rock types used. The cause of this misleading result must be that Milthers ignored most of the possible Swedish indicator types due to his counting procedure. Therefore, when working with mixtures, for example beach stone counts, it is important that the ratio of recognized stones to all stones is about the same for all till beds exposed in the locality dealt with. In the above example Milthers counted a much lower percentage of the total stone content from the "Swedish" till than from the "Norwegian" one.

Because too few specimens of porphyry can be found when counting in situ, Milthers was forced to count among stones already outwashed, either by nature (beach stones), or by man (e.g. gravel pit stones). Stones on beaches and in gravel pits represent mixtures. Counts in piles of field stones result in under-representation of some rock types, for example Dala porphyries (Krüger 1974), because only larger stones are gathered by the farmer.

The Åland rocks make up a special problem in Milthers' rock type selection, because they have a larger parent area than most porphyries. As a consequence they can outnumber any porphyry type in a count, especially when working with mixtures. For example, a total of 12 Åland stones and 6 Dala porphyries were registered by the present author in his two counts from Ristinge (tables 1,2). Five of the Alland specimens were found in the NE-ice till, but they were outnumbered there by 32 specimens of Swedish rock types not used by Milthers. It is, therefore, reasonable to conclude that if Åland rocks are 


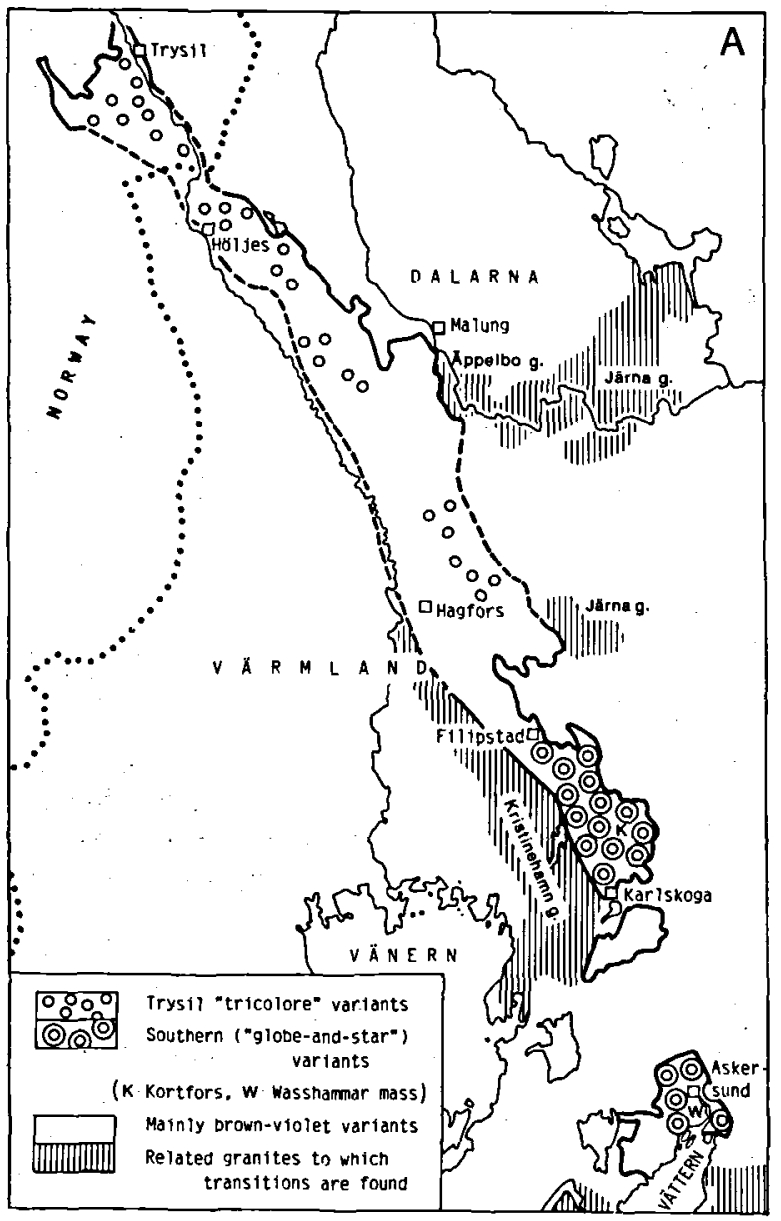

to be counted, they must be counterweighted by also counting granites and other rock types with equivalently large parent areas from Sweden and Norway.

The above examples emphasize the already mentioned under-representation of Swedish rocks in Milthers' counts. Therefore, the ice advances from Norway and from the Baltic depression were identified by Milthers with a certain success, but the NE-ice till was not recognized as a unit. In Ristinge cliff the NE-ice till was interpreted by K. Milthers (1942) as deposited by a socalled Dala-Baltic advance following a routeway from Dalarna across the Åland area and the Baltic sea and perhaps crossing Scania on its way to Denmark. More recently, HoumarkNielsen (1987) rejected the existence of such an ice advance.

Granite identification. It is a common opinion among Danish geologists that only few granite types can be used as indicators, because of the following reasons: (1) Granite types may be difficult to recognize. However, this is not always the case. For example, erratics of the "Tricol-

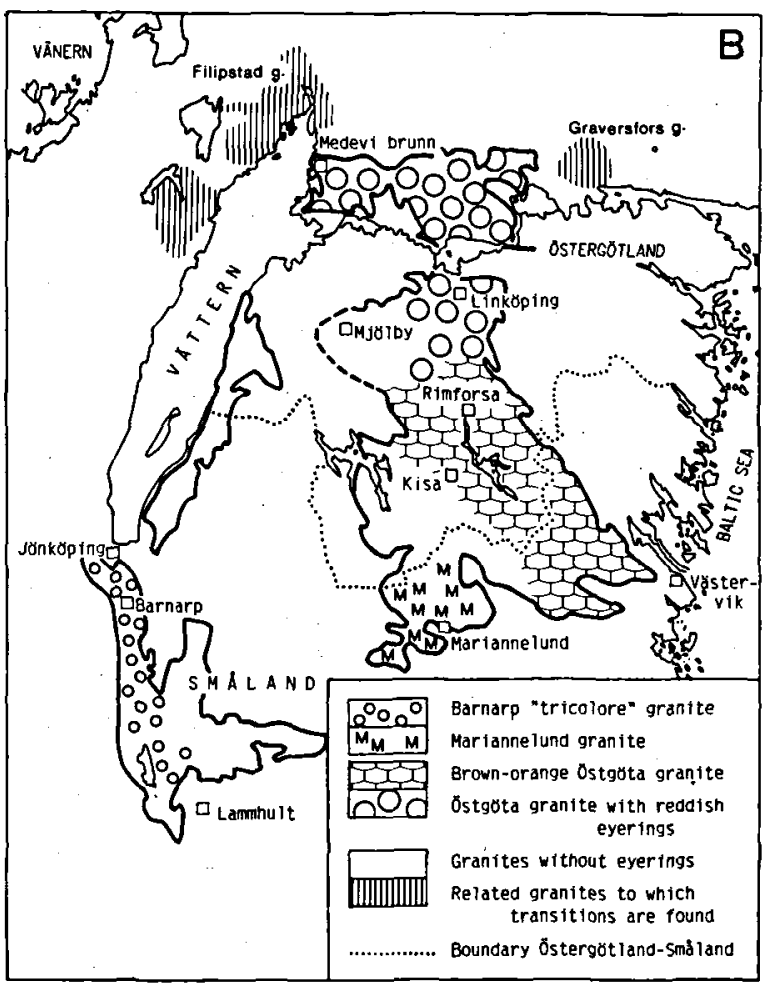

Fig. 3. Maps showing parent areas of (A) some subtypes of Filipstad granite, and (B) variants of "eyegranite" from Småland and Östergötland. For location see Figure 2. As the boundaries between the granite variants are not mapped by the Geological Survey of Sweden (SGU), only an approximate distribution of main variety groups can be shown.

Table 2. Indicator count B in the young Baltic till in Ristinge cliff, Langeland, Denmark. The index numbers refer to same numbers as shown in Fig. 5.

\begin{tabular}{llc}
\hline $\begin{array}{l}\text { Index } \\
\text { No. }\end{array}$ & Indicator type & $\begin{array}{c}\text { Number of } \\
\text { specimens }\end{array}$ \\
\hline 19 & Särna porphyry & 1 \\
22 & Venjan porphyrite & 1 \\
25 & Östgöta granite, reddish-eyed & 1 \\
27 & Red Smăland granites & 8 \\
36 & Rödö rapakivi & 1 \\
37 & Sala granite & 2 \\
38 & Uppsala granite & 2 \\
39 & Stockholm granite & 1 \\
40 & Brown Baltic porphyry & 1 \\
41 & Red Baltic sandstones & 8 \\
43 & Palaeozoic limestones & 35 \\
44 & Bornholm gneiss & 4 \\
46 & Aland rapakivi & 3 \\
46 & Aland granite & 3 \\
\hline
\end{tabular}

Total

69 
ore" granite, or the Uppsala granite, are easier to recognize than most porphyries from Dalarna (Smed 1989). Many granite types with well-defined distribution areas can be identified on the basis of colour, crystal sizes and shapes, and other macroscopic textural features which can easily be seen with the naked eye, or by using a magnifying glass (Smed 1989). (2) Some granite types vary over short distances in an unclear or multitudinous way. But this is also the case with other rocks, for example some porphyries. Many granites have inapplicable variants, but also usable subtypes; as an example see fig. 3. The inapplicable variants and other stones which cannot be recognized with certainty must be excluded from the counts. The purpose is not to identify all stones obtained, but to count the reliable specimens only.

At present, about $25 \%$ of all granite stones found in Denmark can be determined. Even so, far more recognizable granites than porphyries occur in Danish localities. For example, from the NE-ice till exposed in Ristinge cliff 19 recognizable granites and 6 porphyries were obtained and from the Baltic till 22 granites and 3 porphyries (tables 1, 2).

It should be noted that granite types from regional groups of parent areas are found together. This emphasizes their value as indicators. Examples: Stockholm, Uppsala, Sala, and Vänge granites occur in the same localities; Blekinge granites accompany white-spotted flints; when Filipstad granites are found in abundance, Kristinehamn granites occur too. Furthermore, a certain relationship normally exists between the number of specimens of each rock type. For example, on Gilleleje beach, Sjælland, 28 Filipstad granites, 8 Kristinehamn granites, and 24 Dala porphyries were found. The relative frequency corresponds well to the relative size of the parent areas. A high frequency of certain erratics in a count is, however, often caused by short distance from the parent area to the locality dealt with.

Possible errors due to differences in knowledge. An objection against indicator counting which is often put forward is that a subjective element is involved; different investigators recognize different rock types. If the difference in knowledge affects single rock types only, then the general picture changes very little according to the author's experience. However, if none of the abundantly found indicators from western Sweden, such as Kinne "diabase", granate amphibolite, Filipstad and Kristinehamn granites, are used by an investigator, then large interpretation errors can arise. Therefore, it is proposed to divide the Scandinavian and Baltic regions into some districts, for instance 10, and then to learn 2-4 important indicator types from each district, including "small" as well as "large" rock types. Knowledge about less commonly found types is not necessary.

Statistical requirements. Some authors recommend 100 stones in a count. Schuddebeurs (1980), who counted several times in the same till, concluded that if fewer than
50 indicators were counted, the figures were not reliable. The present author has found that 50 stones will give a clear picture and is, therefore, a reasonable requirement.

\section{Description of localities and documentation of counts}

The following section outlines the geology of two Danish localities (fig. 1) and presents four indicator counts made by the author by using Hesemann's rock selection and the in situ count procedure.

Ristinge cliff. The stratigraphy was discussed by Madsen (1916), Rosenkrantz (1944), Andersen (1945), Ehlers (1978), Sjørring et al. (1982), and Sjørring (1983). The southwestfacing cliff section displays more than 30 glacial slabs stacked in an imbricated structure by an ice push from southeast (Sjørring 1983). The slabs are combined of marine Eemian clay overlain by two Weichselian tills: a lower "thin till", $1 \mathrm{~m}$ thick, identified as an old Baltic till (most probably identical with the till deposited by the Brandenburg ice advance in Germany), and an upper "thick till", $3 \mathrm{~m}$ thick, representing the NE-ice advance which reached the Main Stationary Line in central Jylland. Some boulders in the "thick till" showed a NE-SW striation. The glacio-tectonically disturbed series is overlain discordantly by young Baltic till consisting of a lower clayey and a more sandy upper unit separated by glaciofluvial deposits (Sjørring et al. 1982, Sjørring 1983). The sandy unit is interpreted as identical with the Bælthav till (Houmark-Nielsen 1987) and the Sehberg till in Germany (Stephan et al. 1983).

Count A (table 1) was made in the NE-ice till (slabs nos 15-18), count B (table 2) in a low southeastern part of the cliff where only the uppermost sandy till unit is exposed.

The cliffs by Fakse Ladeplads. The stratigraphy was described by Ødum (1933) and Petersen \& Konradi (1974). At Strandegårds Dyrehave, $3 \mathrm{~km}$ southwest of Fakse Ladeplads, the southeast-facing cliff section can be divided into a southem dislocated part and a northern undisturbed, or slightly disturbed, part. Here, near the beach Ievel marine Eemian clay crops out. The marine series is overlain by Weichselian old Baltic till, 1-2 m thick, which contains a considerable number of red sandstones and Palaeozoic limestones. Some boulders showed striae SE-NW. The old Baltic till is overlain by till, 4-6 m thick, deposited by the NE-ice. This till is locally dominated by a large number of clasts of White Chalk, Danian limestone, and dark flint. Several inclusions and schlieren of sorted sand and smudges of White Chalk occur in the till. The uppermost part of the cliff consists of $1-3 \mathrm{~m}$ young Baltic till.

The young Baltic till also appears in a low cliff $2-3 \mathrm{~km}$ 
Table 3. Indicator count $\mathrm{C}$ in the NE-ice till by Strandegårds Dyrehave, southwest of Fakse Ladeplads, Zealand, Denmark. Index numbers refer to same numbers as shown in Fig. 5 .

\begin{tabular}{llc}
\hline $\begin{array}{l}\text { Index } \\
\text { No. }\end{array}$ & Indicator type & $\begin{array}{c}\text { Number of } \\
\text { specimens }\end{array}$ \\
\hline 16 & Granate amphibolite & 5 \\
20 & Dala sandstone & 5 \\
21 & Dala ignimbrite & 1 \\
21 & Grönklitt porphyrite & 1 \\
21 & Other Dala porphyries & 3 \\
22 & Venjan porphyrite & 1 \\
23 & Rätan granite & 2 \\
26 & Kinda granite (Östergötland) & 1 \\
27 & Red Småland granites & 10 \\
$27 c$ & Virbo granite & 1 \\
29 & Påskallavik porphyry & 3 \\
30 & Pink Växjö granite & 9 \\
31 & Spinkamăla granite & 2 \\
31 & Karlshamn granite & 1 \\
32 & White-spotted flint & 4 \\
33 & Scanian basalt & 9 \\
41 & Red sandstones (- No. 20) & 2 \\
43 & Palaeozoic limestones & 8 \\
\hline Total & & 69 \\
\hline
\end{tabular}

northeast of Fakse Ladeplads where the boundary between this till and the underlying NE-ice till is wellmarked, partly by a shear plane, partly by a clast pavement, or a layer of sorted sand. A slight soil development suggests the existence of an ice-free time interval prior to deposition of the young Baltic till. The young Baltic till consists of two units: the uppermost $0.3-1 \mathrm{~m}$, light in colour, is strongly fissile. It is separated by a thin layer of sorted sediment from an underlying brownish till showing more spaced joints. According to till fabric analyses made by Krüger (1969) and by the present author this brownish till was deposited by ice flowing from eastsoutheast; the uppermost parts, however, from southsoutheast.

Count $\mathrm{C}$ (table 3 ) was made both in the dislocated and in the undisturbed parts of the NEice till exposed in the Strandegårds Dyrehave cliff, count D (table 4) in the lower Baltic till unit $3 \mathrm{~km}$ northeast of Fakse Ladeplads.

\section{Discussion of data-presentation methods}

The data-presentation procedure proposed by Hesemann (1931) divides Scandinavia and the Baltic sea into four parent regions (fig. 4). All rock specimens originating from each area were summarized, and the four sums were expressed as percentages of the total number of stones in the count. The last digit in each figure was rounded to the nearest $10-\%$ interval, and the zero was removed. The four one-digit numbers achieved made up the so-called "Hesemann formula". As an example, the formula 7120
Table 4. Indicator count D in the young Baltic till in the cliff 3 $\mathrm{km}$ northeast of Fakse Ladeplads, Zealand, Denmark. Index numbers refer to same numbers as shown in Fig. 5 .

\begin{tabular}{llc}
\hline $\begin{array}{l}\text { Index } \\
\text { No. }\end{array}$ & Indicator type & $\begin{array}{c}\text { Number of } \\
\text { specimens }\end{array}$ \\
\hline 27 & Red Småland granites & 2 \\
35 & Revsund granite & 1 \\
38 & Arnö granite & 1 \\
38 & Vänge granite & 1 \\
39 & Stockholm granite & 1 \\
41 & Red sandstones & 26 \\
42 & Kalmarsund sandstones & 1 \\
43 & Palaeozoic limestones & 61 \\
44 & Hammer granite & 1 \\
46 & Åland granite & 7 \\
46 & Aland rapakivi & 1 \\
\hline Total & & 103 \\
\hline
\end{tabular}

means that round $70 \%$ of the stones in the count originate from the Alland-Finland-Lapland area (I), $10 \%$ from the Dalarna-Stockholm-central Baltic area (II), 20\% from southern Sweden and southern Baltic (III), and 0\% from Norway (IV). In the Hesemann formula the occurrence, or absence, of each separate rock type is not shown. However, it is important for the conclusion, whether a count contains Bohuslen granites, Kinne "diabases", rock types from Blekinge or Bornholm, or limestones from Gotland - all pooled in one region (III) by Hesemann. All these rock types cannot be carried from their parent areas to a specific locality in Denmark by the same ice advance.

The circle-map method. Due to the above-mentioned ob-

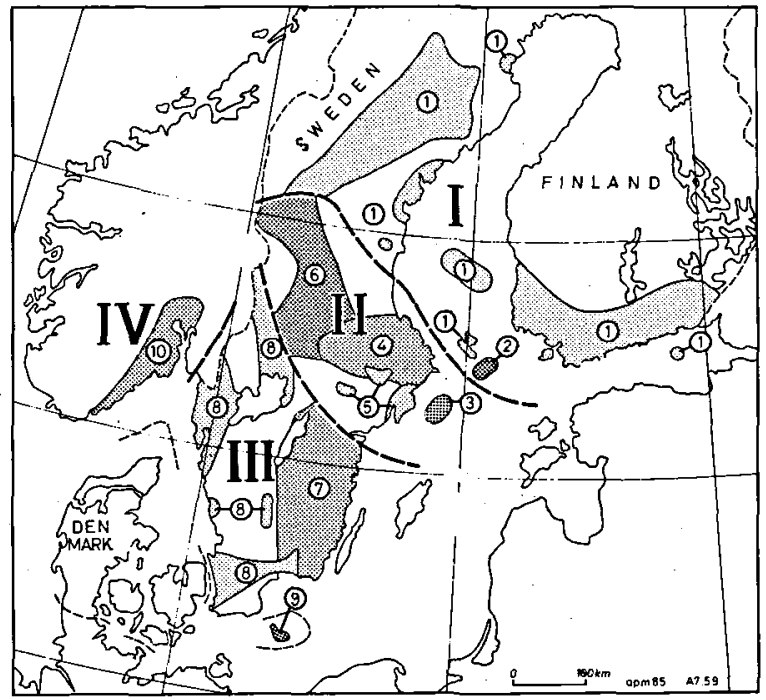

Fig. 4. Hesemann's (1931) subdivision of Scandinavia into four regions, I-IV. The numbers $1-10$ refer to the subdivision made by RGD (the Geological Survey of the Netherlands). 


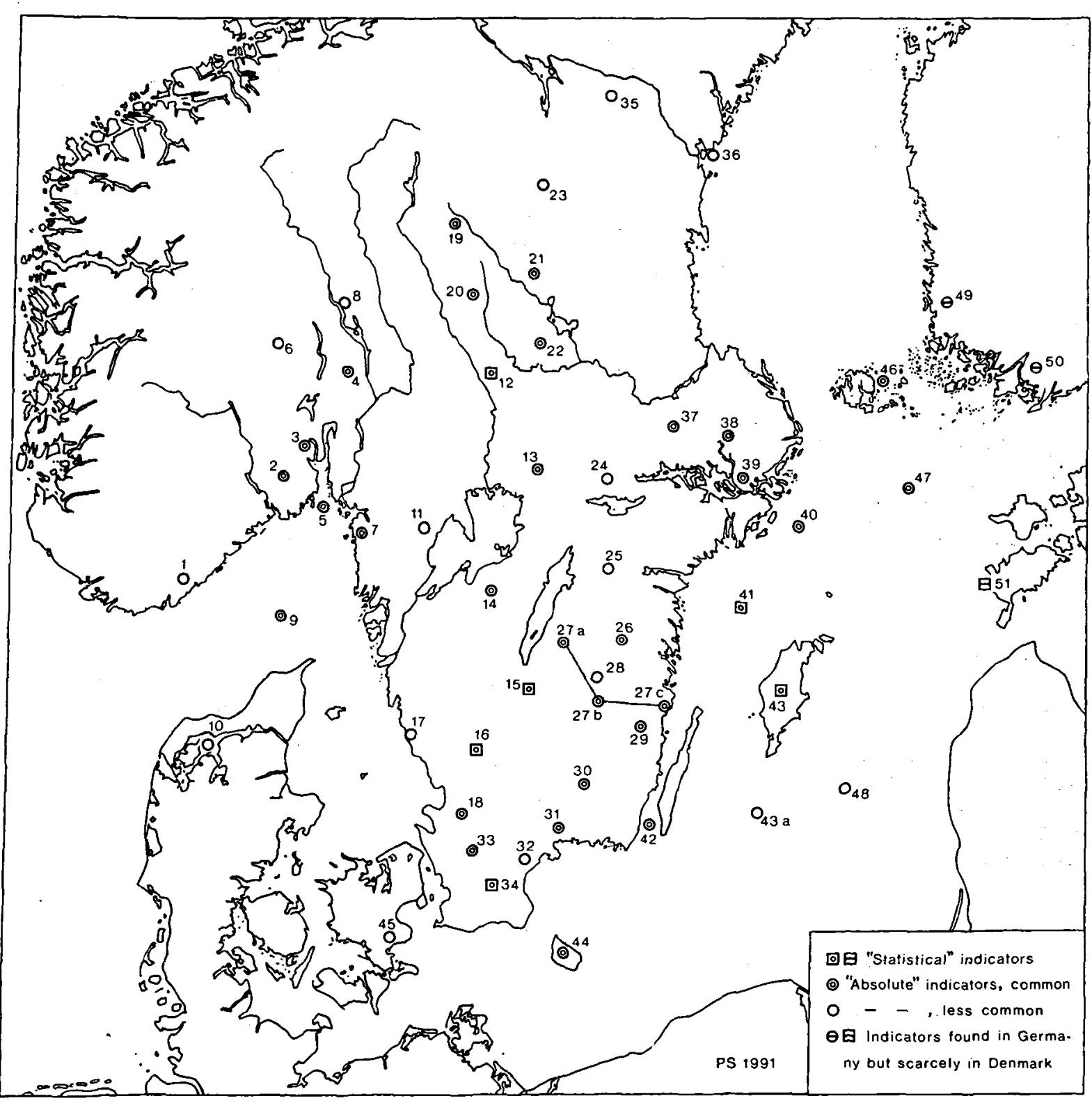

Fig. 5. Map showing the geographical centers of the parent areas of indicators used by the author. The numbers indicate the following rock types: 1, Grimstad/Herefoss granite; 2, Larvikite, ekerite, nepheline syenite, grorudite; 3 , Rhomb porphyry and all other Oslo field rocks except 2,4 , and $5 ; 4$, Nordmarkite; 5 , Rhomb porphyry conglomerate; 6 , Hedal granite; 7, Bohuslen granite; 8 , Biskopåsen conglomerate; 9, Flint conglomerate; 10, Cement stone from the moler clay; 11, Åmål and Kroppefjäll gneiss-granite; 12, Filipstad granite, the Trysil-tricolore and brown-violet variants as well as unspecified specimens; 13, Filipstad granite, the southern variants, and Kristinehamn granite; 14, Kinne "diabases"; 15, Barnarp tricolore granite and Vaggeryd syenite; 16, Granate amphibolite; 17, Varberg charnockite; 18, Scanian granulite; 19, Särna porphyry, Säma "diabase", and Säma tinguaite; 20, Öje "diabase", Heden porphyry, Dala sandstone; 21 , Rocks from Dalarna except 19, 20, and 22; 22, Siljan and Järna granite, Venjan porphyrite; 23, Rätan granite; 24, Fellingsbro granite; 25, Graversfors granite and reddish-eyed Östgöta granite; 26, Kinda granite; 27, Red Småland granites; 28, Mariannelund granite and Sjögelö, Nymåla, Lönneberga, and Fagerhult porphyries; 29, Påskallavik porphyry and specimens of Småland dike porphyries others than 28; 30, Växjö granites, pink and grey; 31, Karlshamn and Spinkamåla granites; 32, Whitespotted flint; 33, Scanian basalt; 34, White Scolithus sandstone; 35, Revsund and Ragunda granites; 36, Rödö rocks; 37, Sala granite; 38, Uppsala, Vänge, and Arnö granites; 39, Stockholm granite; 40, Brown Baltic porphyry; 41, Red Cambrian sandstone; 42, Kalmarsund sandstone; 43, Palaeozoic limestone; 43a, Beyrichia limestone; 44, Bornholm rocks; 45, Fakse coral limestone; 46, Åland rocks; 47, Red Baltic porphyry; 48, Devonian "old red" sandstone; 49, Rocks from the Nystad areas; 50 , Perniö granite; 51, Dolomites. For description of rock types see Zandstra (1988) and Smed (1989). 

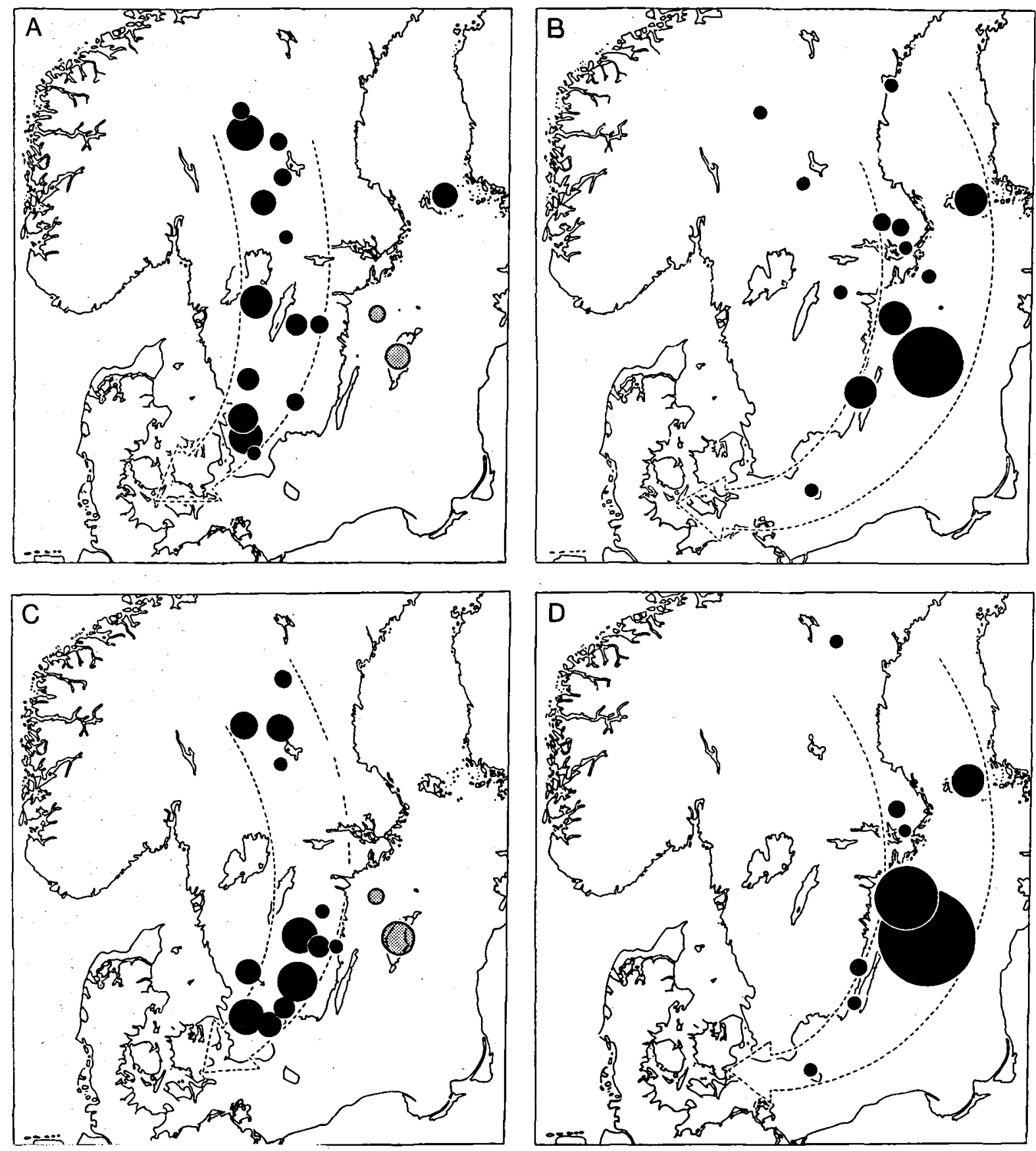

Fig. 6. Circle maps showing the results of counts A-D. (A) The NE-ice till in Ristinge cliff. (B) The young Baltic till in Ristinge cliff. (C) The NE-ice till in Strandegårds Dyrehave cliff southwest of Fakse Ladeplads. (D) The young Baltic till in the cliff $2 \mathrm{~km}$ northeast of Fakse Ladeplads. For an explanation of the data presentation see text.

jection against the use of the Hesemann formulae the author presents data from indicator counts in a new way which is described as follows: a map of Scandinavia has been made where the geographical center of the parent area of each indicator type is marked (fig. 5); only certain rock types with closely spaced parent areas are pooled, for example Uppsala, Arnö, and Vänge granites, as well as most rock types from the Oslo field. Every indicator type (or pooled group) in a count is then depicted on a smaller map as a circle with an area proportional to the number of specimens found and with the centers of the circles placed in the centers of the individual parent areas 
(fig. 6 A-D). On all the maps, the smallest circle represents one specimen. The use of grey colour in some circles (fig. 6A, 6C) is explained below.

The circle maps show the routway of ice flow from the Scandinavian mountains to the locality in Denmark as a band. Tills of different provenience display different bands, even in cases where contamination probably exists, for example the Åland rocks in count A.

Comments on the signatures in figs. 5-6. The following rock types present special problems:

1. Red Småland granites have huge parent areas which permit them to occur both in "Swedish" and in Baltic tills. Most probably their parent areas continue beneath the Baltic sea (fig. 2). If they are depicted by $27 \mathrm{a}$, or $27 \mathrm{~b}$ (fig. 5), but in reality are picked up outside the coastline by $27 \mathrm{c}$, then the picture of the provenience of the till may be disturbed. An advice could be to allow a choice between $27 \mathrm{a}, \mathrm{b}$, and $\mathrm{c}$ when drawing the circle in question.

2. Dala sandstones and red Baltic sandstones cannot always be distinguished from one another. According to Schuddebeurs (1980) and confirmed by the present author, specimens showing circular light spots (reduction patches) come from Dalarna only, whereas "true red" specimens without spots originate from either of the areas. In this work all red sandstones without patches are shown by 41 (fig. 5); if they make up less than $80 \%$ of all red sandstones in a count, a doubtindicating signature (grey) has been used. If specimens without spots exceeds $80 \%$ of all red sandstones, they have been regarded as Baltic indicators and are shown the normal way (black).

3. Palaeozoic limestones originate mostly from the Baltic depression. Their large number in count $B$ suggests that the few specimens of limestone clasts registered in count A result from contamination when the old Baltic till was overridden by the NE-ice. However, Palaeozoic limestones appear also in several minor areas in central Sweden. So, if this rock type in a count occurs in a number comparable to crystalline indicator types, it has no value as indicator. When occurring in very large numbers Palaeozoic limestones suggest a Baltic provinience of the till. Consequently, in this work Palaeozoic limestones are shown by a doubt-indicating signature (grey), if their number is less than double of the most abundant crystalline rock type, and depicted the normal way (black), if their number exceeds this demand.

Hesemann's method compared to the circle-map method. Hesemann worked mainly with crystalline rocks. If sedimentary rocks are included, however, the Hesemann formula for counts A and B can be calculated to be 1270 and 1370 , respectively. The difference is negligible. Compared to the clear difference between the two circle maps (figs 6A, 6B) the result based on the Hesemann formulae is useless. If sedimentary indicators are excluded, the formulae for counts A and B are 1180 and 3340, respectively. In this case the difference is significant, but it is noteworthy that the largest figure in both formulae refers to the same region (III). The most visible "signal" from formula 3340 is that the counted stones originate from most areas of Finland and Sweden, but with reference to fig. 6B, this "signal" is wrong.

Other points of criticism against Hesemann's datapresentation method are as follows: (1) Hesemann divides the Baltic sea area between the Groups I, II, and III.
However, figs 6B and 6D show that granite types from the Stockholm (Uppland) area, Åland rocks, Gotland limestones, and Bornholm rocks accompany one another in Danish tills, but they are not found together with rocks from central or western Sweden. This point disappears when the Hesemann formulae are used. (2) Region II includes both rocks from Dalarna and from Uppland (Stockholm area). However, figs 6A-6D suggest that rocks from Dalarna and Uppland were transported to Denmark along different routeways of ice flow: apparently, the Uppland granites accompany Baltic indicators, whereas indicators from Dalarna are found together with stones from southeast or southwest Sweden. (3) As mentioned above, Region III is much too large for Danish purposes. In Denmark, Bohuslen granites are mainly found in "Norwegian" tills; Kinne "diabases" and Filipstad granites are typical NE-ice indicators; Bornholm and Kalmarsund rocks were transported to western Denmark by the Baltic ice advances.

The RGD method. RGD (Rijks Geologische Dienst, the Netherlands) has authorized a datapresentation method in which consequences are taken of the criticism against Hesemann by making the groups of parent areas smaller. For Danish purposes, however, this method is not ideal either, because Bohuslen granites, Filipstad granites, and rocks from Scania and Blekinge are still pooled in the same group. Bohuslen and Blekinge rocks cannot be transported to Sjælland by the same ice flow.

The Lüttig method. Lüttig (1958) published a list of more than 400 Scandinavian indicator types with specifications of the latitudes and longitudes of the centers of the parent areas. The longitudes of all rock specimens in a count were summed up, and the sum was divided with the number of stones. The latitudes were treated the same way. The resulting two figures, which represent the average longitude and latitude of the parent areas of all stones in the count, are coordinates defining a point on the globe. In German counts this point, named TGZ (Theoretisches Geschiebe-Zentrum), is normally situated in eastern Sweden. Typically, counts in different tills have different TGZs. The TGZs of counts A-D were calculated. The TGZ of count $A$ is situated in the northern end of lake Vättern; for count $C$ the TGZ is located a little more southerly, near Tranås in Northwest Småland. Both for counts B and D the TGZ is located in the Baltic sea between Gotland and the town Nyköping on the Swedish east coast. Thus, the counts make up two pairs, a "Swedish" one and a "Baltic" one. The TGZs of counts A and C suggest a lateral displacement of the routeway of ice flow.

In Germany, the TGZ-method is regarded to be more suitable to reveal the provenience of tills than that of Hesemann (Woldstedt \& Duphorn 1974). This judgment is confirmed by the calculations above. Further advantages are that arbitrary divisions of Scandinavia as well as 
proportionals are avoided. However, in comparison to the circle-map method details are lost.

Contamination. None of the methods used by Milthers, Hesemann, RGD, or Lüttig answer the important question: which of the registered stones were brought directly to the locality and which ones result from contamination? The following two examples demonstrate that the circlemap method presents a possibility to handle this problem. In fig. 6A the Aland rocks are separated from the main band by an interval. On the map shown in fig. 5 this interval is covered by several numbered points, but rock types representing these parent areas were not recognized in the till. It should be noted, that rock types with the signature "less common" in fig. 5 cannot be used in such a judgement. This suggests that the Åland rocks were picked up from an older till by the overriding glacier somewhere in Denmark. In fig. 6B small circles, each representing one stone, cover the points 19 and 22 in Dalarna. This suggests contamination, because the adjacent points 12,20 , and 21 are empty. Note that, if fewer than 50 stones are counted, the band is perhaps fragmentary, and empty areas cannot be demonstrated, if large "blind" areas exist without points on the map shown in fig. 5 .

Lateral displacement of the ice flow. The most striking feature in count $C$ (Fakse Ladeplads) is that Kinne "diabases" are absent; they do not occur on the beach either. Generally, this rock type is one of the most frequent indicators in NE-ice tills. For example, among 218 registered stones on Ristinge beach 16 were Kinne "diabases". Only Växjö granites, granate amphibolites, and Scanian basalts were more frequent. A comparison with count A which was also made in NE-ice till, but in Ristinge cliff suggests that the absence of Kinne "diabases" in count $\mathrm{C}$ results from a lateral displacement towards the east of the routeway of ice flow which passed the Fakse area. The absence of Filipstad granites combined with the presence of Rätan granites in the northern end of the band suggests such a displacement too.

The lateral displacement of the NE-ice flow as indicated by counts $\mathrm{A}$ and $\mathrm{C}$ can define the limits of the bands (the dotted arrows in fig. 6). First, it is evident that the western limit of the band in fig. $6 \mathrm{C}$ must be drawn east of the Kinne "diabase" and the Filipstad granite areas. Secondly, the band has to exclude the area of Scanian granulite in northwest Scania. Thirdly, the eastern limit of the band must lie more easterly than the band shown in fig. 6A, but still west of the Uppland granites (these rock types occur in the young Baltic till in the same locality, but not in the NE-ice till). Fourthly, the sandstones in count $\mathrm{C}$ are certainly from Dalarna. Therefore, the sandstone area in Kalmarsund and northwards has to be excluded. In this way, both the eastern and western limits of the band in fig. 6C are fairly precisely determined. Apparently, the granate amphibolites lie outside the band. However, this rock type is a "statistical in- dicator", and considerable areas of it are exposed in northern Scania. To indicate this, a tiny arrow was placed by the amphibolite circle in fig. $6 \mathrm{C}$.

The demarcation of the bands makes is possible to estimate the size of the lateral displacement of ice flow. It should be noted, however, that the till in the two localities is not necessarily deposited at the same time; the direction of ice flow can change in the course of one ice event The arrows in fig. 6 indicating direction of ice flow accord with other evidence of ice movement direction across Denmark, Scania, and central Sweden, such as glacial striae and till fabric analyses.

\section{Conclusion}

The requirements of indicator counting can be summarized as follows: (1) A count should comprise at least 50 stones, taken in situ in the till. (2) Both "small" and "large" indicator types should be included. (3) Rock types selected should have parent areas as evenly distributed as possible throughout the Scandinavian and Baltic regions.

The advantages of the circle-map method can be summarized as follows: (1) The method does not conceal any field information. (2) An arbitrarily drawn subdivision of Scandinavia into regions is avoided. (3) The method makes it possible to distinguish between directly brought stones and stones resulting from contamination. (4) The method emphasizes the detailed variations in indicator content and may, therefore, show the lateral displacement of the ice flow. (5) It is the only method which points out the precise routeway of ice flow in a large scale and, therefore, makes indicator counting a fruitful supplement to the other methods used in glacial geology.

\section{Acknowledgements}

From the outset, this indicator research project was supported by advice received from Johannes Krüger, Institute of Geography, and Steen Sjørring, Institute of Geology, University of Copenhagen. An indicator collection of Swedish rock types was made available by Johannes Krüger, who has also given helpful comments on the manuscript, especially by shortening and improving the text. Klaus-Dieter Meyer, Niedersächsisches Landesamt für Bodenforschung, Hannover, Jürgen Ehlers, Geologisches Landesamt Hamburg, G. Steinich, Uwe Strahl, and Karsten Schütze, Greifswald, Germany, encouraged the study. Hugo Wikman, Geological Survey of Sweden, Lund, and Jørgen Trelle Pedersen, Nordborg, Denmark, provided assistance by identifying rock types. Margit Johansen, Aase Mikkelsen, Finn Uno Kofoed, and Anne Marie Rasmussen assisted me in the field, and Jette 
Glyholt kindly improved the English of the manuscript. To all of these people I am extremely grateful.

\section{Dansk sammendrag}

I mange år har interessen for ledeblokstudier i Danmark været ringe, ud fra en opfattelse af, at Milthers (1909) klassiske ledebloktællingsmetode - der kun inddrager få bloktyper - fører til forkerte resultater.

Denne artikel indledes med en oversigt over generelle problemer knyttet til ledebloktælling. Disse er: Forskelle i middelkornstørrelse fra bjergart til bjergart, forskelle i bjergarternes modstandsdygtighed overfor glacial erosion og transport, samt kravene til valg af bloktyper. Centrale svagheder ved Milthers ledebloktællingsmetode diskuteres og demonstreres: (1) Blokudvalget er for snævert, fordi det næsten udelukkende udgøres af porfyrer; (2) selv i de tilfælde, hvor tællingerne også omfatter kinnediabas og skånsk basalt, giver resultaterne mulighed for fejltolkninger; (3) mange tællinger domineres af Ålandsblokke, fordi Milthers ikke også har talt bjergartstyper med tilsvarende store hjemstedsarealer i Sverige og Norge; (4) Milthers blokselskab resulterer i en overrepræsentation af norske og baltiske blokke, mens svenske sten underrepræsenteres; (5) for at opnå et tilstrækkeligt antal sten var Milthers nødsaget til at udføre sine tællinger på lokaliteter med omlejret eller indsamlet materiale - på stranden, i grusgrave og i markstensbunker.

For at opnå holdbare resultater skal ledebloktællinger udføres in situ i till-bænke, og der skal - som anbefalet af Hesemann $(1931,1936)$ og Krüger (1974) - tælles på et stort udvalg af bjergarter med hjemsteder spredt javnt ud over Skandinavien og det baltiske område (fig. 2). Dette dokumenteres på to udvalgte lokaliteter, Ristinge klint (Langeland) og Fakse Ladeplads (Sjælland), hvor der er udført ledebloktællinger in situ i henholdsvis $N \emptyset$-is till og baltisk till (tabel 1-4).

Dernæst diskuteres afbildningsmetoder. Hesemann (1931) inddelte Skandinavien og det baltiske område $\mathrm{i}$ fire regioner (fig. 4); de talte blokke på en lokalitet blev delt $\mathbf{i}$ fire grupper svarende til de pågaldende regioner. Det vises, at denne metode ikke kan anvendes i Danmark. Andre metoder benyttet i Holland og Tyskland diskuteres. Der foreslås en ny afbildningsmåde, cirkelkortmetoden: På et kort over Skandinavien vises centrum for de benyttede ledeblokkes hjemsteder (fig. 5). For hver ledebloktælling angives den enkelte bloktype på et mindre kort som en cirkel, hvis centrum anbringes i centrum af den respektive bloktypes hjemsted. Cirklens areal er proportional med blokantallet. Herved fremtræder et bånd af cirkler, som viser isens vej fra de skandinaviske fjelde til den pågældende lokalitet i Danmark (fig. 6).

Det konkluderes, at cirkelkortmetoden giver et langt mere detaljeret billede af isens bevægelsesveje end de talformler, der hidtil har været anvendt (Hesemann 1931,
Milthers 1942, Lüttig 1958), og resultaterne er mere entydige. Tills med forskellig proveniens har distinkt forskellige kortbilleder. Cirkelkortmetoden giver - som den eneste metode hidtil - mulighed for at frasortere sten, som isen ikke har transporteret med fra hjemstedet, men har optaget fra en underliggende till.

\section{References}

Andersen, S. A. 1945. Isstrømmenes Retning over Danmark i den sidste Istid, belyst ved Ledeblokundersøgelser. Meddr. dansk geol. Foren. 10, 594-615.

Boulton, G. S. 1974. Processes and patterns of glacial erosion. In Coates, D. R. (ed.): Glacial geomorphology. State Univ. New York, 41-87.

Ehlers, J. 1978. Fine gravel analysis after the Dutch method as tested out on Ristinge Klint, Denmark. Bull. geol. Soc. Denmark, 27, 157-165.

Gry, H. 1974. Ledeblokkes kornstørrelsesforhold og transportmåde. Dansk geol. Foren. Årsskr. 1973, 140-151.

Hesemann, J. 1931. Quantitative Geschiebebestimmungen im norddeutschen Diluvium. Jb. preuss. geol. L-anst. N.F. 51, 714-758.

Hesemann, J. 1935. Ergebnisse und Aussichten einiger Methoden zur Feststellung der Verteilung kristalliner Leitgeschiebe. Jb. preuss. geol. Lanst. 55, 1-27.

Hesemann, J. 1936. Zur Petrographie einiger nordischer kristalliner Leitgeschiebe. Abh. preuss. geol. L-anst. N.F. 173, 1167.

Hesemann, J. 1975. Kristalline Geschiebe der nordischen Vereisungen. Geol. L-amt Nordrhein-Westfalen, Krefeld. 267 p.

Houmark-Nielsen, M. 1987. Pleistocene stratigraphy and glacial history of the central part of Denmark. Bull. geol. Soc. Denmark, 36, 1-198.

Humlum, O. 1985. Changes in texture and fabric of particles in glacial traction with distance from source, Myrdalsjökull, Iceland. Jl. Glaciol. 31, 150-156.

Krüger, J. 1969. Landskabsformer i sydlige Sjælland. Geogr. Tidsskr. 68, 105-212.

Krüger, J. 1974. Ledeblokkes egnethed til brug i kvantitative analyser. Dansk geol. Foren. Ärsskr. 1973, 152-161.

Lüttig, G. 1958. Methodische Fragen der Geschiebeforschung. Geol. Jb. 75, 361-418.

Madsen, V. 1916. Ristinge klint. Danm. geol. Unders. IV, 1, 2, $1-32$.

Meyer, K.-D. 1983. Indicator pebbles and stone counts. In Ehlers, J. (ed.): Glacial deposits in north-west Europe. Balkema, Rotterdam, 275-287.

Milthers, K. 1941. Stenene og det danske Landskab. Dansk Natur - Dansk Skole. Hagerup. 59 p.

Milthers, K. 1942. Ledeblokke og Landskabsformer i Danmark. Danm. geol. Unders. II, 69, l-121.

Milthers, V. 1909. Scandinavian indicator boulders in the Quaternary deposits. Danm. geol. Unders. II, 23, 1-153.

Milthers, V. 1934. Die Verteilung skandinavischer Leitgeschiebe im Quartär von Westdeutschland. Abh. preuss. geol. L-anst. N.F. 156, 1-74.

Petersen, K.S. \& Konradi, P. 1974. Lithologisk og palæontologisk beskrivelse af profiler i kvartæret på Sjælland. Dansk geol. Foren. Årsskr. 1973, 47-56.

Rosenkrantz, A. 1944. Nye bidrag til forståelsen af Ristinge klints opbygning. Meddr. dansk geol. Foren. 10, 431-435.

Schuddebeurs, A.P. 1980-81. Die Geschiebe im Pleistozän der Niederlande. Der Geschiebesammler. Hamburg, 13.-14.-15. Jahrg. 137 p.

Sjørring, S. 1974. Klinterne ved Hundested. Dansk geol. Foren. Årsskr. 1973, 108-117.

Sjørring, S. 1983. Ristinge klint. In Ehlers, J. (ed.): Glacial 
deposits in north-west Europe. Balkema, Rotterdam, 219226.

Sjørring, S., Nielsen, P.E., Frederiksen, J., Hegner, J., Hyde, G., Jensen, J. B., Mogensen, A., \& Vortisch, W. 1982. Observationer fra Ristinge klint, felt- og laboratorieunders $\emptyset$ gelser. Dansk geol. Foren. Årsskr. 1981, 135-149.

Smed, P. 1989. Sten i det danske landskab. Geografforlaget. 181 p.

Stephan, H.-J., Kabel, C., \& Schlüter, G. 1983. Stratigraphical problems in the glacial deposits of Schleswig-Holstein. In Ehlers, J. (ed.): Glacial deposits in north-west Europe. Balkema, Rotterdam, 305-324.
Sugden, D. E. \& John, B. S. 1976. Glaciers and landscape. Arnold, London. 376 p.

Wennberg, G. 1949. Differentialrörelser i inlandsisen. Medd. Lunds geol.-mineralog. Inst. 114, 1-201.

Woldstedt, P. \& Duphorn, K. 1974. Norddeutschland und angrenzende Gebiete im Eiszeitalter. Koehler, Stuttgart. 500 p. Zandstra, J. G. 1988. Noordelijke kristallijne Gidsgesteenten. Brill, Leiden. 469 p.

Ødum, H. 1933. Marint interglacial på Sjælland, Hven, Møn og Rügen. Danm. geol. Unders. IV, 10, 1-44. 